\title{
Pain incidence, assessment, and management in Vietnam: a cross-sectional study of 12,136 respondents
}

This article was published in the following Dove Medical Press journal: Journal of Pain Research

\author{
Nguyen Van Chuong' \\ Dinh Cong Pho ${ }^{2}$ \\ Nguyen Thi Thanh Thuy ${ }^{3}$ \\ Dinh Toan Nguyen ${ }^{4}$ \\ Nguyen The Luan ${ }^{5}$ \\ Luu Hong Minh ${ }^{5}$ \\ Luong Thi Khai ${ }^{6}$ \\ Nguyen Thuy Linh ${ }^{3}$ \\ Nguyen Trung Kien ${ }^{7}$ \\ 'Department of Neurology, Military \\ Hospital 103, Vietnam Military \\ Medical University, Ha Noi, Vietnam; \\ ${ }^{2}$ Faculty of Medicine, Vietnam Military \\ Medical University, Ha Dong District, \\ $\mathrm{Ha}$ Noi, Vietnam; ${ }^{3}$ General Hospital \\ District No 8, Ho Chi Minh City, \\ Vietnam; ${ }^{4}$ Hue Medical and Pharmacy \\ University, Hue City, Vietnam; ${ }^{5}$ Tien \\ Giang University, My Tho City, Tien \\ Giang Province, Vietnam; ' ${ }^{\circ}$ ang Son \\ Medical Institute, Lang Son City, Lang \\ Son Province, Vietnam; ${ }^{7}$ Department \\ of Anesthesia and Pain Medicine, \\ Military Hospital 103, Vietnam Military \\ Medical University, Ha Noi, Vietnam
}

Correspondence: Nguyen Trung Kien Department of Anesthesia and Pain Medicine, Military Hospital 103, Vietnam Military Medical University, 26I Phung Hung Road, Ha Dong District, $\mathrm{Ha}$ Noi 100000, Vietnam

Tel +84979800922

Email drkien103@gmail.com
Objective: To describe the rate and demographics of pain among Vietnamese people in 48 provinces and describe the impact of pain on individuals, levels of satisfaction with treatment results, and behavior of pain sufferers.

Methods: The cross-sectional study was conducted in adults presenting to outpatient clinics throughout 48 provinces in Vietnam and were randomly selected for inclusion in this study. A physician trained to administer a questionnaire in a standardized fashion interviewed each patient and collected data regarding gender, age, career, acute and chronic pain, diagnoses, treatment, and satisfaction with treatment.

Results: There were 12,136 respondents ( $50.65 \%$ male and $49.35 \%$ female) from 48 of the 63 provinces in Vietnam. About $86.53 \%$ of respondents reported experiencing pain that affected their daily lives, with $24.10 \%$ complaining of acute pain and $62.43 \%$ having chronic pain. About $67.71 \%$ reported pain that affected job performance. Headache was the most common complaint in $35.43 \%$ of the respondents. Fewer than half (43.35\%) of all patients with pain sought help from a doctor; only a quarter $(27.50 \%)$ sought help within 1 month of experiencing that pain. A majority (61.98\%) of patients who did seek help were satisfied with treatment results. The median cost of treatment was between 150 and 250 USD.

Conclusion: Pain severe enough to impact patients' daily lives is common in Vietnam. Treatment costs are a significant economic burden and may help explain why only a minority of patients seek treatment. Access to lower cost, effective treatment for pain should be improved. Keywords: survey, chronic pain, impact of pain, health care, Vietnamese adults

\section{Introduction}

Pain is a common health care problem not only in terms of medical effects but also due to its socioeconomic impact. Many large-scale epidemiological surveys of pain have been conducted in developed countries such as Germany, the Netherlands, Canada, Japan, and other countries. ${ }^{1-5}$ Causes of chronic pain were different between surveys and countries, but the most common were osteoarthritis and lower back pain..$^{6-9}$ The results in some studies have shown that the rate of chronic pain is higher in females than in males. ${ }^{10-12}$ Chronic pain is associated with increasing age and the elderly are the most vulnerable population to suffer from. ${ }^{12,13}$ In developing countries, chronic pain is of more concern as it leads to decreasing quality of life. Inadequate or undertreated chronic pain affects people's daily activities and behavior which in turn contribute to a substantial rate of depression and anxiety. Few reports have investigated the prevalence of pain in community and reflected the real status about how chronic patients were managed. ${ }^{14-16}$ Currently, there is no any published epidemiological data concerning pain in Vietnam. 
The objectives of this study were to 1) determine the prevalence and demographics of pain in Vietnam's 48 provinces; 2) explore the impact of pain on daily activities including employment; and 3) gain a better understanding of the practices, cost, and satisfaction associated with treatment.

\section{Methods}

The cross-sectional study was conducted in adults presenting to outpatient clinics. Data were collected between December 2014 and May 2015. Our investigators surveyed hospitals in 48 of the 63 provinces, representing all seven economic regions of Vietnam (Table 1).

The Vietnamese population in 2015 was used as the standard population.

All the respondents received care in outpatient facilities at center of medicine or clinics. Respondents were excluded from the study if they were younger than 10 years. Respondents with pain who were currently involved in clinical trials were excluded to ensure that the data reflected respondents who were receiving standard treatment for their pain. Our questionnaire (Figure S1) was adapted from the one used by Breivik et al. ${ }^{5}$ The interviews were conducted in Vietnamese. The corre- sponding author (Nguyen Trung Kien) translated the original questionnaire to a Vietnamese version before starting study. All patients provided written informed consent. The study was conducted in accordance with the Declaration of Helsinki.

The initial questionnaire was a screening interview to assess the rate of pain within each province, age and gender of respondents, the duration of pain, time when pain occurred, location of pain. The respondents were considered to suffer from chronic pain if they have 1) pain persisting for $\geq 3$ months, 2) pain felt within the preceding 1 month, and 3) frequency of pain feeling $\geq 2$ times/week. Respondents who fulfilled these screening criteria of the initial screening questionnaire were then interviewed in depth. Questions in the in-depth interview assessed: 1) demographics; 2) frequency, duration, and intensity of pain; 3 ) the impact of pain on respondents' work and quality of life; 4) attitude of respondents toward their pain and its treatment; 5) respondents' interaction with health care professionals, including how many doctors respondents had visited, how often they had seen them, and how long they had been seeing them; and 6) treatments, including prescription and non-prescription medicines and non-medication strategies.

Table I Survey site

\begin{tabular}{|c|c|c|c|c|}
\hline \multirow[t]{3}{*}{ Serial no. } & \multirow[t]{3}{*}{ Province name } & \multicolumn{3}{|c|}{ Respondents } \\
\hline & & \multirow[t]{2}{*}{ Number } & \multicolumn{2}{|c|}{ Gender } \\
\hline & & & Male & Female \\
\hline 01 & Bac Giang & 343 & 169 & 174 \\
\hline 02 & Bac Kan & 137 & 79 & 58 \\
\hline 03 & Bac Lieu & 77 & 39 & 38 \\
\hline 04 & Bac Ninh & 58 & 26 & 32 \\
\hline 05 & Binh Dinh & 312 & 142 & 170 \\
\hline 06 & BinhThuan & 22 & 12 & 10 \\
\hline 07 & Ben Tre & 334 & 175 & 159 \\
\hline 08 & Ca Mau & 63 & 29 & 34 \\
\hline 09 & Can Tho & 106 & 33 & 73 \\
\hline 10 & Cao Bang & 24 & 10 & 14 \\
\hline II & Dac Lak & 73 & 34 & 39 \\
\hline 12 & Dien Bien & 55 & 18 & 37 \\
\hline 13 & Dong Nai & 507 & 265 & 242 \\
\hline 14 & Dong Thap & 51 & 25 & 26 \\
\hline 15 & Gia Lai & 1,012 & 508 & 504 \\
\hline 16 & $\mathrm{Ha} \mathrm{Nam}$ & 15 & 9 & 6 \\
\hline 17 & $\mathrm{Ha}$ Noi & 1,038 & 500 & 538 \\
\hline 18 & $\mathrm{Ha}$ Tinh & 24 & 12 & 12 \\
\hline 19 & Hai Duong & 59 & 26 & 33 \\
\hline 20 & Hai Phong & 291 & 164 & 127 \\
\hline 21 & Hau Giang & 59 & 31 & 28 \\
\hline 22 & HCM City & $\mathrm{I}, 224$ & 800 & 424 \\
\hline 23 & Hoa Binh & 27 & 15 & 12 \\
\hline 24 & Hung Yen & 7 & 4 & 3 \\
\hline
\end{tabular}

\begin{tabular}{|c|c|c|c|c|}
\hline \multirow[t]{3}{*}{ Serial no. } & \multirow[t]{3}{*}{ Province name } & \multicolumn{3}{|c|}{ Respondents } \\
\hline & & \multirow[t]{2}{*}{ Number } & \multicolumn{2}{|c|}{ Gender } \\
\hline & & & Male & Female \\
\hline 25 & Khanh Hoa & 200 & 102 & 98 \\
\hline 26 & Kien Giang & 55 & 29 & 26 \\
\hline 27 & Lam Dong & 133 & 61 & 72 \\
\hline 28 & Lang Son & 356 & 105 & 251 \\
\hline 29 & Lao Cai & 82 & 32 & 50 \\
\hline 30 & Long An & 134 & 60 & 74 \\
\hline 31 & Nam Dinh & 583 & 262 & 321 \\
\hline 32 & Nghe An & 397 & 223 & 174 \\
\hline 33 & Ninh Binh & 411 & 213 & 198 \\
\hline 34 & PhuTho & 543 & 290 & 253 \\
\hline 35 & Quang Binh & 63 & 26 & 37 \\
\hline 36 & Quang Ninh & 72 & 25 & 47 \\
\hline 37 & Quang Tri & 229 & 72 & 157 \\
\hline 38 & Soc Trang & 77 & 36 & $4 I$ \\
\hline 39 & Son La & 87 & 39 & 48 \\
\hline 40 & Thai Binh & 186 & 104 & 82 \\
\hline 41 & \begin{tabular}{|l|} 
Thai Nguyen \\
\end{tabular} & 197 & 93 & 104 \\
\hline 42 & Thanh Hoa & 133 & 61 & 72 \\
\hline 43 & Thua Thien Hue & 795 & 387 & 408 \\
\hline 44 & Tien Giang & 930 & 493 & 437 \\
\hline 45 & Tuyen Quang & 22 & 9 & 13 \\
\hline 46 & Vinh Long & 74 & 36 & 38 \\
\hline 47 & Vinh Phuc & 282 & 156 & 126 \\
\hline 48 & Yen Bai & 177 & 108 & 69 \\
\hline
\end{tabular}

Notes: Total, 12,136 (male $=6,147[50.65 \%]$ and female $=5,989[49.35 \%]$ ). 
Doctors working at general hospitals and medical centers in the provinces were selected to interview patients, and were trained to administer the questionnaire in a standardized fashion. The survey data were collected and analyzed in one center. Data were analyzed by SPSS software version 20.1.

This study was performed after obtaining approval from the ethics committee of Military Hospital 103.

\section{Results}

Of the 12,136 respondents screened, 10,501 (86.53\%) had experienced significant pain at some time during their lives, with 7,576 (62.43\%) reporting pain that was chronic in nature. A total of 3,247 (26.76\%) respondents had experienced pain for at least 12 months. In total, 10,501 respondents reported suffering from pain and their interviews yielded the following data.

\section{Demographics}

Patients who reported pain were evenly distributed between the two genders ( $50.65 \%$ female, $49.35 \%$ male). Those under 40 years of age appeared to suffer less, whereas the 41-70 years age group appeared to more likely suffer from pain than others (Table 2).

\section{Pain characteristics}

The duration of pain was often prolonged. A majority of respondents suffered from chronic pain, as mentioned previously (62.43\%; Table 3$)$.

Table 2 Age of respondents

\begin{tabular}{|l|l|l|}
\hline Age (years) & Number & Percentage \\
\hline $10-19$ & 1,711 & 16.29 \\
\hline $20-29$ & 2,979 & 28.37 \\
\hline $30-39$ & 1,721 & 16.39 \\
\hline $40-49$ & 1,692 & 16.11 \\
\hline $50-59$ & 982 & 9.35 \\
\hline $60-69$ & 665 & 6.33 \\
\hline $70-79$ & 401 & 3.82 \\
\hline $80-89$ & 267 & 2.54 \\
\hline$>90$ & 83 & 0.65 \\
\hline
\end{tabular}

Table 4 presents the most commonly reported body locations and causes of pain. Headache and neck/back pain were most common.

The intensity of reported pain is presented in Table 5 .

\section{Impact of pain}

Impact of pain on daily activities

To gauge the impact of pain on respondents' lives, the interviewers read a list of activities and asked respondents if their daily activities or employment activities were limited by pain. About $86.53 \%$ of the respondents reported that pain affected their daily lives and $67.71 \%$ reported that pain affected their jobs.

\section{Treatment practice}

\section{Respondent's attitudes}

The interviewers read a list of statements to respondents to determine their attitudes and beliefs about their pain. About $81.46 \%$ of respondents considered their pain to be a part of their medical condition.

\section{Pain management}

The services patients sought for treatment are shown in Figure 1. The most common method was self-treatment.

\section{Visits to doctors}

About $43.35 \%$ of respondents $(4,553)$ had visited doctors; $63.42 \%$ of them had seen their doctor in the first month, while only $2.55 \%$ had seen their doctor after 1 year. About $56.65 \%$ of respondents had not seen their doctor at all (Table 6).

\section{Satisfaction with treatment for pain}

About $42.89 \%$ of respondents were satisfied with the treatment they received for their pain, while $19.99 \%$ were unsatisfied and $3.23 \%$ had nothing to disclose (Table 7).

\section{Cost of pain treatment}

According to the 7,537 respondents who answered to the question regarding the cost of treatment, the median cost

Table 3 Duration of pain

\begin{tabular}{|c|c|c|c|c|c|c|c|c|}
\hline \multirow{2}{*}{$\begin{array}{l}\text { Duration of } \\
\text { pain (months) }\end{array}$} & \multicolumn{4}{|c|}{ In-depth interview $(\mathrm{N}=\mid \mathbf{0 , 5 0 I})$} & \multirow{2}{*}{\multicolumn{3}{|c|}{ Screening (\%), $(N=12,136)$}} & \multirow{2}{*}{$\begin{array}{l}\text { Type of } \\
\text { pain }\end{array}$} \\
\hline & Number of patients & \multicolumn{3}{|c|}{ Percentage } & & & & \\
\hline$<3$ & 2.925 & \multicolumn{3}{|l|}{27.85} & \multicolumn{3}{|l|}{24.10} & Acute \\
\hline $3-5$ & 2.299 & 21.89 & & \multirow[t]{4}{*}{72.15} & 18.94 & & \multirow[t]{4}{*}{62.43} & \multirow[t]{4}{*}{ Chronic } \\
\hline $6-12$ & 2.030 & 19.33 & & & 16.73 & & & \\
\hline $13-24$ & 1.473 & 14.03 & \multirow[t]{2}{*}{30.92} & & 12.14 & \multirow[t]{2}{*}{26.76} & & \\
\hline$>24$ & 1.774 & 16.89 & & & 14.62 & & & \\
\hline
\end{tabular}


Table 4 Body locations of pain

\begin{tabular}{|l|l|}
\hline Location & Percentage \\
\hline Head & $68.71 \%$ \\
\hline Face & $4.87 \%$ \\
\hline Neck & $11.26 \%$ \\
\hline Upper limbs & $8.14 \%$ \\
\hline Shoulder & $5.02 \%$ \\
\hline Arm & $4.44 \%$ \\
\hline Elbow & $3.83 \%$ \\
\hline Hand & $2.57 \%$ \\
\hline Finger & \multicolumn{2}{|l|}{} \\
\hline Lower limbs & $6.47 \%$ \\
\hline Buttock & $2.68 \%$ \\
\hline Thigh & $4.01 \%$ \\
\hline Leg & $2.59 \%$ \\
\hline Foot & $2.04 \%$ \\
\hline Toe & $27.75 \%$ \\
\hline Back pain & $4.42 \%$ \\
\hline Chest & $13.53 \%$ \\
\hline Abdomen & \\
\hline Joint of upper limbs & $6.09 \%$ \\
\hline Shoulder & $4.42 \%$ \\
\hline Elbow & $4.61 \%$ \\
\hline Wrist & $3.41 \%$ \\
\hline Metacarpal & $1.66 \%$ \\
\hline Finger & $2.23 \%$ \\
\hline Joint of lower limbs & $5.68 \%$ \\
\hline Hip & $3.33 \%$ \\
\hline Knee & $2.99 \%$ \\
\hline Ankle & $1.54 \%$ \\
\hline Metatarsal & \multicolumn{2}{|l|}{} \\
\hline Toe & \\
\hline \multicolumn{2}{|l|}{} \\
\hline \multicolumn{1}{|l|}{} \\
\hline
\end{tabular}

Table 5 Intensity of pain

\begin{tabular}{|l|l|l|}
\hline \multirow{2}{*}{ Intensity (\%) } & \multicolumn{2}{|l|}{ Respondents (N=I 0,50I) } \\
\cline { 2 - 3 } & Number & Percentage \\
\hline Mild & 2,583 & 24.60 \\
\hline Moderate & 3,137 & 29.87 \\
\hline Severe & 2,190 & 20.86 \\
\hline Very severe & 298 & 2.84 \\
\hline Unexplained intensity & 2,293 & 21.83 \\
\hline
\end{tabular}

of treatment was between 150 and 250 USD. Only a small number of persons $(0.20 \%)$ paid more than 1,000 USD for treatment (Table 8).

\section{Discussion}

It is clear from this large-scale survey of 12,136 respondents that pain is very common in Vietnam. Data were collected from 48 of the 63 provinces, which included all seven major economic areas in Vietnam. Doctors involved in conducting the survey were trained in social communication and administering the questionnaire. Thus, we are confident that the specific prevalence data for pain are valid for the documented provinces.

Geographically, respondents included in this study were located throughout Vietnam. Twenty-six provinces had over 100 respondents and two large cities (Hanoi and Ho Chi Minh City) accounted for more than 1,000 respondents each.

Our result showed that nearly all respondents suffered from significant pain at some point in their lives, and that chronic pain impacting daily activities and employment was very common. One reason that the prevalence of pain was high in this study may be that we surveyed persons who had presented to an outpatient clinic with some complaint, as opposed to a random survey of the population at large. Therefore, our pre-test probability was likely elevated. Interestingly, this result is similar to the study of Boerlageand et al, which found that the prevalence of chronic pain was $69 \%$ in three Dutch residential homes. ${ }^{2}$ In postal surveys, the prevalence was $39.3 \%$ in Japan and $35.5 \%$ in Ireland. ${ }^{4,16}$ With telephone interviewing, with or without the assistance of computer, the prevalence of chronic pain was found to vary from $13 \%$ to $45.9 \%$. $^{3,5,7,9,14}$

Our investigation excluded children below the age of 10 years (16.4\% of Vietnam's population per 2015 census data), because the etiology, assessment, treatment, and natural course of pain in children are substantially different from adults. Pain in children is beyond the scope of this study.

The prevalence of pain was high in elderly persons, ${ }^{18,19}$ and management in this population was more complicated. ${ }^{18,20,21}$ The most frequent location of pain was joints, and the rate was found to be higher in females than in males. ${ }^{10-12}$ The results of our study also indicated that the prevalence of pain was higher in females $(53.0 \%)$ than in males. Similar findings have been noted in Libya ${ }^{11}$ and in other countries, particularly in older females. ${ }^{9,10,17}$

Pain is one of the most common reasons for seeking medical attention. People seek health care for pain, not only to improve their physical health but also because pain interferes with psychological and social health. Pain has deleterious effects on mental health, employment status, sleep, and personal relationships. ${ }^{22,23}$ Psychosocial factors, including individual attitudes about pain and learned coping mechanisms, have particularly strong effects upon daily activities and quality of life, in some cases exceeding the influence of simple pain intensity. ${ }^{24}$ Functional limitations vary with the type of pain, with low back and multiple pain localizations correlating with the most functional limitations. ${ }^{24}$ This survey demonstrated that pain has a negative impact on daily activities (88.16\% unpleasant, 67.71\% work-related). 


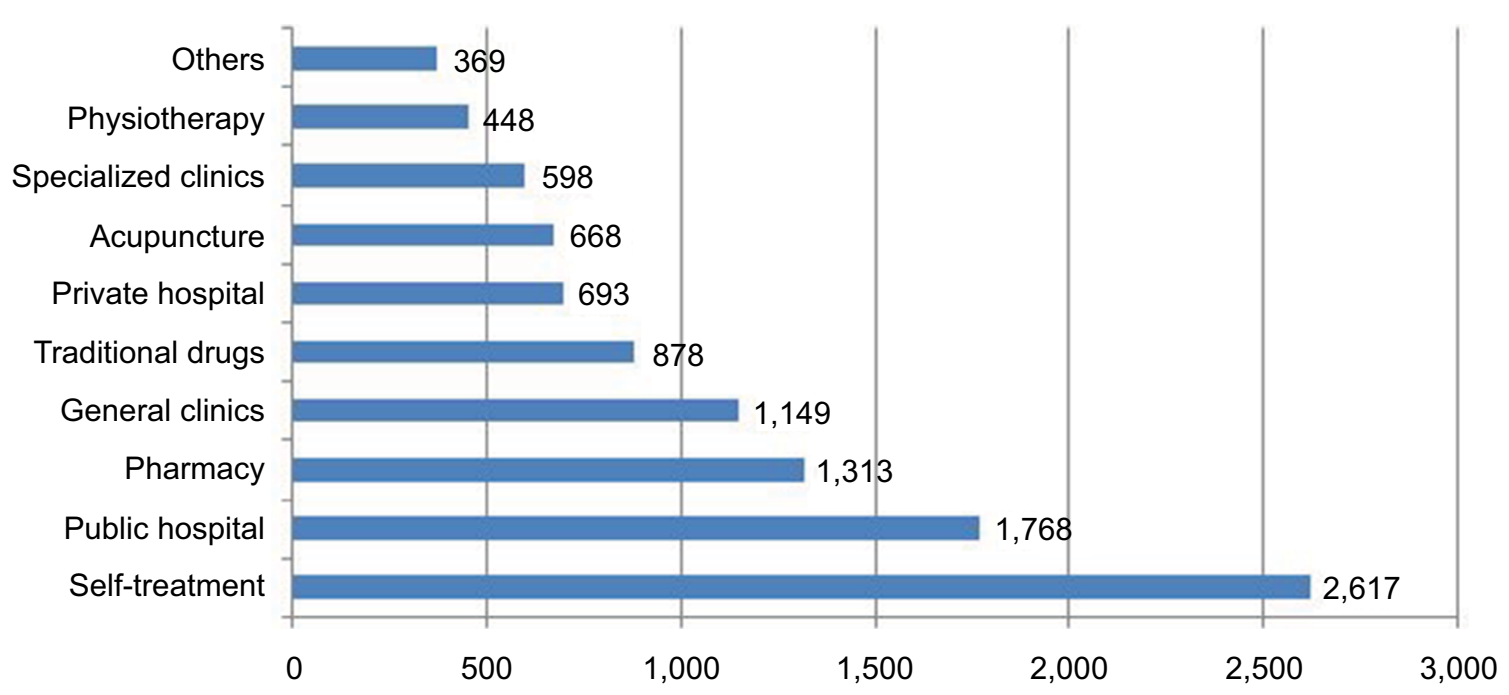

Figure I Pain management.

Table 6 Visits to doctor

\begin{tabular}{|l|l|l|}
\hline \multirow{2}{*}{$\begin{array}{l}\text { Time from onset } \\
\text { to visit (month) }\end{array}$} & Respondents $\mathbf{( N = 4 , 5 5 3 )}$ \\
\cline { 2 - 3 } & Number & Percentage \\
\hline$<1$ month & 2,888 & 63.42 \\
\hline$<6$ months & 926 & 20.33 \\
\hline$<12$ months & 623 & 13.68 \\
\hline$>12$ months & 116 & 2.55 \\
\hline
\end{tabular}

Table 7 Treatment satisfaction

\begin{tabular}{|l|l|l|}
\hline \multirow{2}{*}{ Treatment satisfaction } & \multicolumn{2}{|l|}{ Respondents } \\
\cline { 2 - 3 } & Number & Percentage \\
\hline Extremely satisfied & 732 & 16.08 \\
\hline Satisfied & 1,953 & 42.89 \\
\hline Not satisfied & 910 & 19.99 \\
\hline Extremely not satisfied & $81 \mathrm{I}$ & $17.8 \mathrm{I}$ \\
\hline No comments & 147 & 3.23 \\
\hline
\end{tabular}

Table 8 The cost of treatment for 6 months

\begin{tabular}{|l|l|l|}
\hline \multirow{2}{*}{ Cost } & \multicolumn{2}{|l|}{ Respondents $(\mathbf{N}=\mathbf{1 0 , 5 0 I})$} \\
\cline { 2 - 3 } & Number & Percentage \\
\hline$<150$ USD & 2,649 & 25.23 \\
\hline I50 USD-250 USD & 2,793 & 26.60 \\
\hline 250 USD-500 USD & 1,773 & 16.88 \\
\hline 500 USD-750 USD & 235 & 2.24 \\
\hline 750 USD-I,000 USD & 66 & 0.63 \\
\hline$>I, 000$ USD & 21 & 0.20 \\
\hline No comments & 2,964 & 28.22 \\
\hline
\end{tabular}

Abbreviation: USD, US dollar.

However, the most common choice patients made regarding pain management was self-treatment. Apart from inadequate relief, this may result in delayed diagnosis of related medical problems and a poor prognosis of otherwise treatable ailments. The next most common choices were seeking help at public hospitals, pharmacies, and general clinics. This reluctance to seek professional attention may be rooted in a Vietnamese cultural preference to treat diseases at home rather than in hospital. This might be due to the fact that the professional medical establishment in Vietnam has not paid enough attention to pain management, and that there is room to improve appreciation for diagnosis and treatment of both acute and chronic pain.

Inadequate or undertreated pain significantly reduces the ability of many patients to participate in daily activities and work. An understanding of individual needs is essential in pain management. ${ }^{25}$ In our study, $24.92 \%$ of respondents opted for self-treatment at home. For moderate to severe pain, treatment at home is often suboptimal; $;{ }^{26}$ in many cases, optimal management may require a short course of opioids, ${ }^{27}$ which may be unavailable to those who choose self-treatment. Dureja et al showed that the majority (68\%) of their respondents were treated for pain with over-thecounter (OTC) drugs, and most were taking nonsteroidal drug (95\%). ${ }^{14}$ In Müller-Schwefe's study, 35\% of the respondents took pain medication that was not prescribed by their doctor, ${ }^{28}$ presenting potential safety and legal issues. Breivik's survey of chronic pain in Europe showed that even among patients who sought help from a doctor, very few were managed by pain specialists and $40 \%$ received inadequate pain management. ${ }^{5}$

The current review of literature revealed many factors that limited the possibility of achieving effective pain management by health care systems, medical staff, and patients. ${ }^{29}$ Health care system is the first fundamental barrier 
that is related to poor pain management. According to statistics, patients are likely to not receive analgesic medication when required and treatment is likely to be delayed or ineffective. ${ }^{30,31}$ Vietnam has very limited resources and few pain specialists to care for patients with pain, and medical staff in pain management are not professional as well because there is no any training course in medical universities. Furthermore, other big hindrance is that patients usually buy analgesic agents by themselves from pharmacy store without prescription from doctors (Figure 1). All of these factors led to inadequate pain management among Vietnamese adults.

Other reason is financial problems. The economic burden to the patient is substantial in a developing country. In our survey, the average cost was 200 USD/person. In Vietnam, the poverty threshold is less than $600 \mathrm{USD} /$ year. The cost of pain management represents a significant burden for affected people. Vietnam is a developing country and we must consider how the economic situation of its people affects the prevalence and treatment of pain. In the survey conducted by Tsang et al, there was no obvious association between the prevalence of chronic pain and economic situation. ${ }^{17}$

Satisfaction with treatment is an increasingly popular outcome measure in pain management. In our survey, 58.97\% of respondents were either satisfied or extremely satisfied with their pain control. These results are in line with those reported by McCracken et al. ${ }^{32}$ Importantly, 37.8\% of respondents were either dissatisfied or extremely dissatisfied. We suspect that a combination of inadequate treatment, high cost of treatment, relatively high pain intensity $(23.7 \%$ of our respondents rated their pain as severe), and limitation in health care system are largely responsible for this dissatisfaction. Nursing homes involved in pain management in the Netherlands showed that the satisfaction rate was $60 \%,{ }^{33}$ suggesting that poor pain control may be a worldwide issue. Awareness and knowledge about pain assessment and treatment need to be raised not only for medical staff but also for all residents.

\section{Conclusion}

Pain is common in Vietnam, with headache and neck/back pain accounting for the majority of ailments. Many individuals with chronic pain suffer limitations in their daily activities, including employment. Treatment is often limited by the economic situation of patients and their reluctance to seek professional assistance. There are many opportunities to improve the accessibility and quality of pain management in Vietnam.

\section{Acknowledgments}

The authors thank Mr Gaurav Kumar for his comments on an earlier draft. This research received no specific grant from any funding agency in the public, commercial, or notfor-profit sectors.

\section{Disclosure}

The authors report no conflicts of interest in this work.

\section{References}

1. Hensler S, Heinemann D, Becker MT, et al. Chronic pain in German general practice. Pain Med. 2009;10(8):1408-1415.

2. Boerlage AA, van Dijk M, Stronks DL, de Wit R, van der Rijt CC. Pain prevalence and characteristics in three Dutch residential homes. Eur $J$ Pain. 2008;12(7):910-916.

3. Moulin DE, Clark AJ, Speechley M, Morley-Forster PK. Chronic pain in Canada-prevalence, treatment, impact and the role of opioid analgesia. Pain Res Manag. 2002;7(4):179-184.

4. Inoue S, Kobayashi F, Nishihara M, et al. Chronic pain in the Japanese community - prevalence, characteristics and impact on quality of life. PLoS One. 2015;10(6):e0129262.

5. Breivik H, Collett B, Ventafridda V, Cohen R, Gallacher D. Survey of chronic pain in Europe: prevalence, impact on daily life, and treatment. Eur J Pain. 2006;10(4):287-333.

6. Henderson JV, Harrison CM, Britt HC, Bayram CF, Miller GC. Prevalence, causes, severity, impact, and management of chronic pain in Australian general practice patients. Pain Med. 2013;14(9): 1346-1361.

7. Chung JW, Wong TK. Prevalence of pain in a community population. Pain Med. 2007;8(3):235-242.

8. Watkins EA, Wollan PC, Melton LJ, Yawn BP. A population in pain: report from the Olmsted County health study. Pain Med. 2008;9(2):166-174.

9. Schopflocher D, Taenzer P, Jovey R. The prevalence of chronic pain in Canada. Pain Res Manag. 2011;16(6):445-450.

10. Miró J, Paredes S, Rull M, et al. Pain in older adults: a prevalence study in the mediterranean region of catalonia. Eur J Pain. 2007;11(1):83-92.

11. Elzahaf RA, Johnson MI, Tashani OA. The epidemiology of chronic pain in Libya: a cross-sectional telephone survey. BMC Public Health. 2016;16(1):776.

12. Chrubasik S, Junck H, Zappe HA, Stutzke O. A survey on pain complaints and health care utilization in a German population sample. Eur J Anaesthesiol. 1998;15(4):397-408.

13. Rapo-Pylkkö S, Haanpää M, Liira H. Chronic pain among communitydwelling elderly: a population-based clinical study. Scand J Prim Health Care. 2016;34(2):159-164.

14. Dureja GP, Jain PN, Shetty N, et al. Prevalence of chronic pain, impact on daily life, and treatment practices in India. Pain Practice. 2014;14(2):E51-E62.

15. Sakakibara T, Wang Z, Paholpak P, Kosuwon W, Oo M, Kasai Y. A comparison of chronic pain prevalence in Japan, Thailand, and myanmar. Pain Physician. 2013;16(6):603-608.

16. Raftery MN, Sarma K, Murphy AW, De La Harpe D, Normand C, McGuire BE. Chronic pain in the Republic of Ireland - community prevalence, psychosocial profile and predictors of pain-related disability: results from the Prevalence, Impact and Cost of Chronic Pain (PRIME) study, part 1. Pain. 2011;152(5):1096-1103.

17. Tsang A, Von Korff M, Lee S, et al. Common chronic pain conditions in developed and developing countries: gender and age differences and comorbidity with depression-anxiety disorders. J Pain. 2008;9(10):883-891.

18. Dziechciaż M, Balicka-Adamik L, Filip R. The problem of pain in old age. Ann Agric Environ Med. 2013;1:35-38. 
19. Gunzelmann T, Schumacher J, Brähler E. The prevalence of pain in the elderly German population: results of population-based studies with the Giessen Subjective Complaints List (Giessener Beschwerdebogen GBB). Schmerz. 2002;16(4):249-254. German.

20. Tse M, Leung R, Ho S. Pain and psychological well-being of older persons living in nursing homes: an exploratory study in planning patient-centred intervention. $J$ Adv Nurs. 2012;68(2):312-321.

21. Tse MM, Pun SP, Benzie IF. Pain relief strategies used by older people with chronic pain: an exploratory survey for planning patient-centred intervention. J Clin Nurs. 2005;14(3):315-320.

22. McCarberg BH, Nicholson BD, Todd KH, Palmer T, Penles L. The impact of pain on quality of life and the unmet needs of pain management: results from pain sufferers and physicians participating in an Internet survey. Am J Ther. 2008;15(4):312-320.

23. Smith BH, Elliott AM, Chambers WA, Smith WC, Hannaford PC, Penny K. The impact of chronic pain in the community. Fam Pract. 2001;18(3):292-299.

24. Lamé IE, Peters ML, Vlaeyen JW, Kleef M, Patijn J. Quality of life in chronic pain is more associated with beliefs about pain, than with pain intensity. Eur J Pain. 2005;9(1):15-24.

25. Cherubino P, Sarzi-Puttini P, Zuccaro SM, Labianca R. The management of chronic pain in important patient subgroups. Clin Drug Investig. 2012;32(Suppl 1):35-44.
26. Duke M, Botti M, Hunter S. Effectiveness of pain management in hospital in the home programs. Clin J Pain. 2012;28(3):187-194.

27. Moskovitz BL, Benson CJ, Patel AA, et al. Analgesic treatment for moderate-to-severe acute pain in the United States: patients' perspectives in the Physicians Partnering Against Pain (P3) survey. J Opioid Manag. 2011;7(4):277-286.

28. Müller-Schwefe GH. European survey of chronic pain patients: results for Germany. Curr Med Res Opin. 2011;27(11):2099-2106.

29. Mędrzycka-Dąbrowska W, Dąbrowski S, Basiński A. Problems and barriers in ensuring effective acute and post-operative pain management-an international perspective. Adv Clin Exp Med. 2015;24(5):905-910.

30. Motov SM, Khan AN. Problems and barriers of pain management in the emergency department: are we ever going to get better? J Pain Res. 2008;2:5-11.

31. Taylor AL, Gostin LO, Pagonis KA. Ensuring effective pain treatment: a national and global perspective. JAMA. 2008;299(1):89-91.

32. McCracken LM, Evon D, Karapas ET. Satisfaction with treatment for chronic pain in a specialty service: preliminary prospective results. Eur J Pain. 2002;6(5):387-393.

33. van Herk R, Boerlage AA, van Dijk M, Baar FP, Tibboel D, de Wit R Pain management in Dutch nursing homes leaves much to be desired. Pain Manag Nurs. 2009;10(1):32-39. 


\section{Supplementary material}

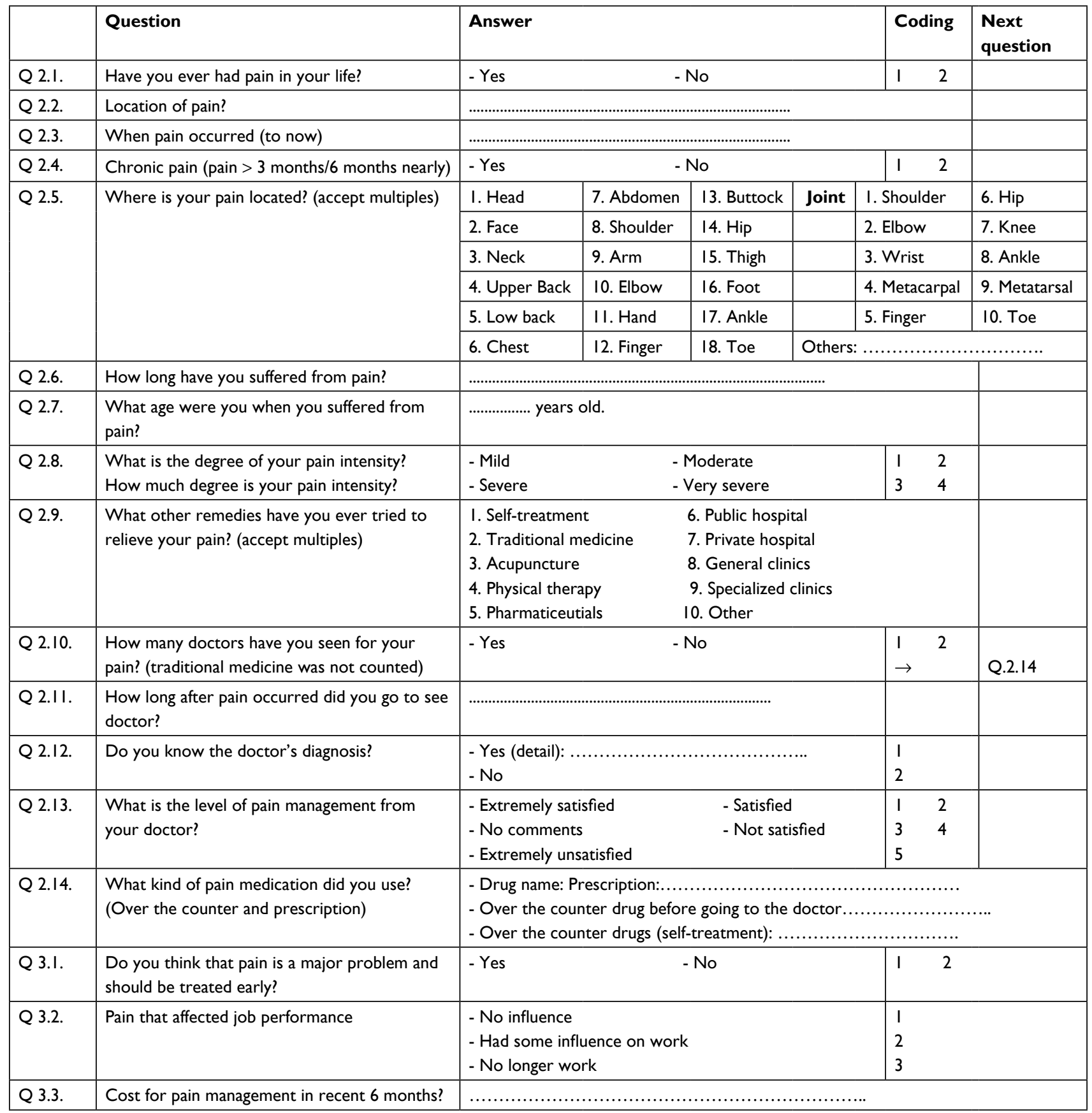

Figure SI Pain survey questionnaire

Notes: Adapted with permission from Breivik H, Collett B, Ventafridda V, Cohen R, Gallacher D. Survey of chronic pain in Europe: prevalence, impact on daily life, and treatment. Eur J Pain. 2006; I0(4):287-333. @ 2005 European Federation of Chapters of the International Association for the Study of Pain. Published by Elsevier Ltd. All rights reserved.' The interviews were conducted in Vietnamese. The corresponding author (Nguyen Trung Kien) translated the original questionnaire to a Vietnamese version before starting study.

\section{Reference}

1. Breivik H, Collett B, Ventafridda V, Cohen R, Gallacher D. Survey of chronic pain in Europe: prevalence, impact on daily life, and treatment. Eur J Pain. 2006;10(4):287-333. 
The Journal of Pain Research is an international, peer reviewed, open access, online journal that welcomes laboratory and clinical findings in the fields of pain research and the prevention and management of pain. Original research, reviews, symposium reports, hypothesis formation and commentaries are all considered for publication
The manuscript management system is completely online and includes a very quick and fair peer-review system, which is all easy to use. Visit http://www.dovepress.com/testimonials.php to read real quotes from published authors.

Submit your manuscript here: https://www.dovepress.com/journal-of-pain-research-journal 